\title{
Desain Penyelesaian Kredit Macet dalam Pembiayaan Murobahah di BMT Bina Ummat Sejahtera
}

\author{
Supriyadi \\ Institut Agama Islam Negeri Kudus \\ supriyadi_rama@yahoo.co.id
}

\begin{abstract}
Financing based on Islamic principles actually to increase employment opportunities and economic prosperity in accordance with the Islamic values. The existence of BMT run financing based on Islamic principles not only for profits and enliven the financing business in Indonesia, but also to create a safe business environment with Islamic principles that do not burden the debtor. One of the financing with the principles of Syariah is financing with the murabahah system. Murabahah financing is a type of purchase contract item with the acquisition price and profit (margin) as agreed by the seller and the buyer where the refund loans by the customer can be done in the form of a mortgage or loan. Loans granted certainly has risk so required ability and effectiveness in managing credit risk and minimize the potential losses. Experienced credit risk is a breakdown of murabahah financing so that need to design a settlement in such financing.
\end{abstract}

Keywords: Design, murabahah financing, settlement

\begin{abstract}
Abstrak
Pembiayaan berdasarkan prinsip syariah sebenarnya untuk meningkatkan kesempatan kerja dan kesejahteraan ekonomi sesuai dengan nilai-nilai Islam. Keberadaan BMT yang menjalankan pembiayaan berdasarkan prinsip syariah bukan hanya untuk mencari keuntungan dan meramaikan bisnis pembiayaan di Indonesia, tetapi juga untuk menciptakan lingkungan bisnis yang aman dengan prinsip syariah yang tidak memberatkan debitur. Salah satu pembiayaan dengan prinsip syari'ah adalah pembiayaan dengan sistem murabahah. Pembiayaan murabahah merupakan jenis akad jual beli barang dengan harga perolehan dan keuntungan (margin) yang disepakati oleh penjual dan pembeli dimana dalam mengembalikan dana pinjaman oleh nasabah bisa dilakukan dalam bentuk cicilan atau kredit. Kredit yang diberikan tentu mengandung resiko sehingga dituntut kemampuan dan efektivitasnya dalam mengelola resiko kredit dan meminimalkan potensi kerugian yang ditimbulkan. Resiko kredit yang dialami adalah macetnya pembiayaan murabahah sehingga perlu melakukan desain penyelesaian dalam pembiayaan tersebut.
\end{abstract}

Kata Kunci : Desain, pembiayaan murabahah, penyelesaian 


\section{PENDAHULUAN}

Di era globalisasi ini sangatlah diharapkan suatu strategi bersaing yang benar-benar handal, karena kondisi dewasa ini semua kegiatan yang menyangkut masyarakat sudah tidak ada lagi batasannya, semua tranparan dan akuntabilitasnya harus dipertanggungjawabkan, baik dalam bidang jasa, lembaga keuangan maupun koperasi. Bentuk usaha koperasi memiliki keunggulan yaitu merupakan gerakan ekonomi rakyat dan mendapat dukungan besar dari pemerintah karena memiliki potensi sangat besar untuk mengembangkan usaha ekonomi rakyat dan mengentaskan kemiskinan. Namun, realitas memperlihatkan perkembangan koperasi hingga kini masih memprihatinkan. Dari 140 ribu koperasi yang ada di Indonesia, termasuk koperasi syariah, hanya sekitar 28,5\% yang aktif dan lebih sedikit lagi koperasi yang memiliki manajemen kelembagaan yang baik, partisipasi anggota yang optimal, usaha yang fokus, terlebih lagi skala usaha yang besar. Sebagai pilar terpenting ekonomi bangsa yang diharapkan menjadi sokoguru perekonomian, secara ironis koperasi justru jauh tertinggal dari badan usaha lainnya dan cenderung dianggap sebagai badan usaha kelas dua. (Republika, 2016)

Dengan keluarnya Undang-Undang No. 10 tahun 1998 yang merupakan revisi dari peraturan pemerintah No. 72 tahun 1992 tentang sebuah bank yang beroperasi dengan sistem bagi hasil, maka seiring dengan hal tersebut banyak pula lembaga keuangan non bank yang muncul dengan sistem bagi hasil. Salah satunya adalah BMT (Baitul Mal Wa Tamwil), yang merupakan lembaga keuangan mikro yang menginduk pada koperasi, sehingga BMT lebih familier dengan koperasi jasa keuangan syariah. Peraturan dan pelaksanaan kegiatannya diatur dalam Keputusan Menteri Negara koperasi dan usaha kecil menengah RI nomor : 91/Kep/M. KUKM/IX/2004 tentang petunjuk pelaksanaan kegiatan usaha koperasi jasa keuangan syariah. Keberadaan BMT ini merupakan salah satu dari lembaga keuangan non bank untuk mewujudkan keinginan khususnya sebagian umat Islam tentang jasa layanan yang berprinsip syariah dalam megelola perekonomiannya. Walaupun kurang lebih telah 12 tahun yang lalu peraturan tentang bank dengan prinsip bagi hasil disahkan, tetapi untuk BMT yang menginduk pada koperasi baru disaahkan tahun 2004 lalu, sehingga praktik lembaga keuangan syariah non bank khususnya BMT masih relatif baru dikalangan masyarakat (Yusuf, 2010:2) yaitu dengan menggunakan model sistem perbankan syariah.

Peran BMT dalam memacu pertumbuhan perekonomian daerah semakin strategis dalam rangka mewujudkan struktur perekonomian yang semakin berimbang. Dukungan terhadap pengembangan perbankan syariah juga diperlihatkan dengan adanya "dual banking system", dimana bank konvensional diperkenankan untuk membuka unit usaha syariah. 
(Harif, 2006:1) Sistem perbankkan Syariah sesungguhnya tidak terbatas pasarnya pada nasabah yang memiliki ikatan emosional keagamaan (masyarakat muslim). Layanan BMT dapat dinikmati oleh siapa saja, tidak tergantung agama yang dianut, sepanjang bersedia mengikuti cara berbisnis yang diperbolehkan secara syariah. Masyarakat membutuhkan lembaga keuangan yang kuat, transparan, adil dan berkomitmen membantu meningkatkan perekonomian dan usaha nasabah. (Lina, 2017:7)

Karakteristik sistem perbankan syariah yang beroperasi berdasarkan prinsip bagi hasil memberikan alternatif sistem perbankan yang saling menguntungkan bagi masyarakat dan bank, serta menonjolkan aspek keadilan dalam bertransaksi, investasi yang beretika, mengedepankan nilai-nilai kebersamaan dan persaudaraan dalam berproduksi, dan menghindari kegiatan spekulatif dalam bertransaksi keuangan. Dengan menyediakan beragam produk serta layanan jasa perbankan yang beragam dengan skema keuangan yang lebih bervariatif, perbankan syariah menjadi alternatif sistem perbankan yang kredibel dan dapat dinimati oleh seluruh golongan masyarakat Indonesia tanpa terkecuali. (Bank Indonesia, 2011) Namun demikian dalam sistem perbankan syariah lebih kecil mengandung risiko dalam pemberian kredit kepada masyarakat.

Risiko kredit yang dalam bank syariah diistilahkan dengan risiko pembiayaan yang biasanya terjadi jika counterparty tidak bisa memenuhi kewajibannya (wanprestasi). Seringkali adalah para nasabah yang tidak bisa tepat waktu memenuhi kewajiban yang telah ditentukan. Pembiayaan murabahah merupakan salah satu bentuk pembiayaan yang bisa dikatakan mekanisme pembayarannya dilaksanakan secara kredit atau cicilan. Karena pembiayaan murabahah merupakan jenis akad jual beli barang dengan menyatakan harga perolehan dan keuntungan (margin) yang disepakati oleh penjual dan pembeli dimana dalam mengembalikan dana pinjaman oleh nasabah bisa dilakukan dalam bentuk cicilan atau kredit. Kredit yang diberikan oleh bank mengandung resiko sehingga bank dituntut kemampuan dan efektivitasnya dalam mengelola resiko kredit dan meminimalkan potensi kerugian sehingga bank wajib memperhatikan asas perkreditan yang sehat.

Dalam hal pembiayaan macet pihak BMT perlu melakukan penyelamatan, sehingga tidak akan menimbulkan kerugian. Penyelamatan yang dilakukan apakah dengan memberikan keringanan berupa jangka waktu atau angsuran terutama bagi pembiayaan terkena musibah atau melakukan penyitaan bagi pembiayaan yang sengaja lalai untuk membayar. Terhadap pembiayaan yang mengalami kemacetan sebaiknya dilakukan penyelamatan sehingga bank tidak mengalami kerugian. 
Tujuan pembiayaan berdasarkan prinsip syariah adalah untuk meningkatkan kesempatan kerja dan kesejahteraan ekonomi sesuai dengan nilai-nilai Islam. Keberadaan BMT yang menjalankan pembiayaan berdasarkan prinsip syariah bukan hanya untuk mencari keuntungan dan meramaikan bisnis perbankan di Indonesia, tetapi juga untuk menciptakan lingkungan bisnis yang aman, diantaranya: Memberikan pembiayaan dengan prinsip syariah yang menerapkan sistem bagi hasil yang tidak memberatkan debitur.

Kegiatan usaha berdasarkan prinsip syariah dalam operasionalnya diwujudkan dalam berbagai macam produk pembiayaan perbankan syariah. (Faisal, 2011:3) Menurut Pasal 1 butir (25) Undang-Undang No. 21 Tahun 2008 Tentang Perbankan Syariah dinyatakan bahwa pembiayaan adalah penyediaan dana atau tagihan yang dipersamakan dengan itu berupa transaksi bagi hasil dalam bentuk mudharabah, dan musyarakah, sewa menyewa dalam bentuk ijarah atau sewa beli dalam bentuk ijarah muntahiya bittamlik, jual beli dalam bentuk piutang murabahah, salam dan istisna, pinjam meminjam dalam bentuk piutang qardh, dan sewa menyewa jasa dalam bentuk ijarah untuk transaksi multijasa. Dari berbagai macam produk pembiayaan perbankan syariah seperti diuraikan diatas, murabahah merupakan salah satu bentuk pembiayaan yang paling dominan diterapkan dalam praktik perbankan syariah. Dominasi tersebut hampir mencapai $80-95 \%$ dari setiap pembiayaan dalam lembaga pembiayaan islam yang menggunakan transaksi murabahah.. (Haidar Hamaudi, 2007:119)

BMT Bina Umat Sejahtera (BMT BUS) yang ikut serta berperan aktif untuk meningkatkan kesejahteraan masyarakat. Peran serta tersebut dapat dilihat dari pemberian pembiayaan secara murabahah agar terjadi peningkatan ekonomi masyarakat. Pemberian pembiayaan ini tidak selamanya akan berjalan mulus, dalam artian bahwa terdapat anggota (debitur) yang lancar dalam pengembaliannya dan ada yang macet dalam pembayaran. Terhadap debitur yang lancar dalam pembayaraanya akan meningkatkan kinerja dalam lembaga keuangan akan tetapi terhadap debitur yang macet tentu membawa konsekuensi hukum yang segera perlu mendapatkan penyelesaian. Dan dalam penyelesaiannya tidak boleh merugikan pihak BMT BUS (kreditur) karena telah memberikan dan membantu masyarakat dalam meningkatkan ekonominya.

Dalam kenyataan di lapangan menunjukkan bahwa terdapat debitur (anggota) yang macet dalam pembiayaan murabahah, tidak kooperatif untuk menyelesaikan dengan pihak kreditur yang biasanya mereka tidak mampu membayar dengan alasan yang klasik yaitu faktor ekonomi yang semakin merosot atau dengan alasan-alasan yang tidak 
dapat dipertanggungjawabkan. Melihat kenyataan yang demikian maka pihak krediturlah yang paling banyak dirugikan.

Untuk menyelesaikan masalah tersebut secara normatif maka dapat diproses secara hukum, hal ini dapat meliputi proses litigasi maupun non litigasi. Kedua cara penyelesaian ini tentu memiliki kelebihan dan kekurangan masing-masing. Proses penyelesaian melalui litigasi di dalam pengadilan dan proses non litigasi merupakan penyelesaian sengketa melalui kerjasama (kooperatif) di luar pengadilan. Proses litigasi menghasilkan kesepakatan yang bersifat adversarial yang belum mampu merangkul kepentingan bersama, cenderung menimbulkan masalah baru, lambat dalam penyelesaiannya, membutuhkan biaya yang mahal, tidak responsif dan menimbulkan permusuhan diantara para pihak. Sebaliknya melalui proses non litigasi menghasilkan kesepakatan yang bersifat win-win solution, dijamin kerahasiaan sengketa para pihak, dihindari kelambatan yang diakibatkan karena hal prosedural dan administratif, menyelesaikan secara komprehensif dan kebersamaan dengan tetap menjaga hubungan baik di antara para pihak. (Rahmadi, 2009:3)

Pemberian pembiayaan murabahah di BMT BUS memiliki karakteristik tersendiri, hal ini dapat dilihat dari prinsip pembiayaan murabahah dan pendekatan penyelesaian yang dilakukan dengan prinsip prinsip syariah. Mengedepankan persuasif dan berkeadilan sehingga para pihak yang terlibat dalam penyelesaian tersebut tidak merasa dirugikan. Desain penyelesaian ini diharapkan akan meningkatkan produktifitas yang diharapkan dengan tidak mengecilkan dari anggota (debitur). Berdasarkan uraian di atas maka tujuan penelitian ini adalah : 1) Untuk menemukan faktor-faktor yang mempengaruhi kredit macet dalam pembiayaan murabahah di BMT Bina Ummat Sejahtera, 2) Untuk mengungkap argumentasu secara filosofis dan menganalisis desain penyelesaian kredit macet dalam pembiayaan murabahah di BMT Bina Ummat Sejahtera

\section{METODOLOGI PENELITIAN}

Penelitian ini menggunakan pendekatan Socio legal research, oleh karena itu dalam penelitian ini dilihat dari dua aspek yaitu aspek legal research yang objeknya berupa norma dan socio recearch yaitu dengan menggunakan metode dan teori-teori ilmu sosial tentang hukum untuk membantu peneliti dalam menganalisis. (Zamroni, 1992:80) Penelitian ini masuk ranah Socio legal studies dan dapat di golongkan dalam penelitian sosial tentang hukum yaitu memaparkan suatu realitas sosial yang muncul sebagai akibat pelaksanaan ketentuan hukum sehingga dapat dikategorikan sebagai penelitian non doktrinal. Penelitian ini menggunakan penelitian kualitatif (Robert, 2006:103) prinsipnya dalam penelitian adalah pengumpulan dan analisis data dilakukan secara fleksibel 
melalui kegiatan kegiatan observasi, interview, (Nasution, 1992:9) interpretasi dokumen dan material serta personal experience. (Sanafiah, 1990:80) Interview dilakukan untuk memperoleh deskripsi mengenai aktifitas, tentang penyelesaian kredit macet dalam pembiayaan murabahah. Penelitian ini dilakukan secara indept interview secara terbuka atau tidak terstruktur dengan informan dan secara tertutup dalam hal informan memiliki banyak informasi tetapi ada kendala untuk mengelaborasi informasi tersebut. Dari informan dikembangkan dengan teknik snowball dengan informan lain sesuai dengan kebutuhan penelitian.

\section{HASIL PENELITIAN DAN PEMBAHASAN \\ Faktor Faktor Yang Mempengaruhi Kredit Macet dalam pembiayaan Murabahah.}

Kredit macet atau loan problem adalah kredit yang mengalami kesulitan pelunasan akibat adanya faktor-faktor atau unsur kesengajaan atau karena kondisi di luar kemampuan debitur.(Dahlan, 1993:220) Kredit macet ini dapat juga dialami dalam pembiayaan prinsip murabahah, termasuk yang dialami oleh BMT BUS. Meskipun sebenarnya prinsip murabahah merupakan alternatif positif bagi sebagian masyarakat karena prinsip agama atau kepercayaan tidak bersedia memanfaatkan jasa-jasa bank konvensional yang memiliki prinsip sistem bunga yang dianggap merupakan pelanggaran terhadap syariah agama karena tidak sesuai dengan konsep Islam yaitu perjanjian/akad yang tidak mengandung gharar (ketidak jelasan), maisir (perjudian) dan riba (bunga uang). Muhammad Taqi Usmani mengakui bahwa pada mulanya murabahah bukan merupakan bentuk pembiayaan melainkan hanya alat untuk menghindari "bunga bank" dan juga bukan merupakan instrumen ideal untuk mengembangkan tujuan riil ekonomi Islam. Instrumen murabahah hanya digunakan sebagai langkah transisi yang diambil dalam proses islamisasi ekonomi. Sedangkan untuk menghindari praktik murabahah yang akan terjebak pada praktik hilah, bai' înah, bay'atâni fi bay'ah, dan bai' al-ma'dûm maka para ulama kontemporer mensyaratkan dalam praktik jual beli murabahah di lembaga keuangan syariah sebagai berikut: 1). Jual beli murabahah bukan pinjaman yang diberikan dengan bunga, tetapi merupakan jual beli komoditas dengan harga tangguh termasuk margin keuntungan di atas biaya perolehan yang disetujui bersama. Dalam kaitan ini, bila harga tangguh lebih tinggi dari harga tunai maka sebelum para pihak berpisah, pilihan harga tersebut harus telah disepakati agar terhindar dari bay'atâni fi bay'ah, 2). Pemberi pembiayaan dalam hal ini bank atau lembaga keuangan syariah lainnya, harus telah membeli komoditas/barang dan menyimpan dalam kekuasaannya, atau membeli melalui orang ketiga sebagai agennya sebelum dijual kepada nasabahnya. Bila tidak demikian maka akan terjadi 
bai' al-ma'dûm (menjual belikan sesuatu yang belum ada/dimiliki). Namun demikian, bila pembelian langsung ke pihak supplier tidak praktis, diperbolehkan bagi pemberi pembiayaan untuk memanfaatkan nasabah sebagai agen/wakil dengan menggunakan akad wakalah untuk membeli komoditas yang diperlukan atas nama pemberi pembiayaan. (Unisba, 2016) Oleh karena itu perlu adanya akad yang dibuat secara tertulis sehingga dapat meminimalisir konflik antara kreditur dan debitur dalam pembiayaan murabahah dikemudian hari.

Dalam perspektif hukum Islam murabahah bersifat amanah (kepercayaan) dimana pembeli mempercayai perkataan penjual tentang harga pertama tanpa ada bukti dan sumpah. Dalam hal ini penjual dalam memberikan informasi kepada pembeli tentang biaya-biaya yang dikeluarkan yang merupakan harga pokok pembelian, dan tambahan keuntungan, tidak disertai dengan bukti pembelian. Dalam jual beli murabahah ini kejujuran penjual sangat penting sebagaimana firman Allah dalam (Q.s. al-Anfal (8):27):

$$
\text { يأيها الذين عامنو الاتخونو ا آله وتخونو ا أمنتكم وأنتم تعلمون }
$$

Artinya : " Hai orang-orang yang beriman, janganlah kamu mengkhianati Allah dan Rasul (Muhammad) dan (juga) janganlah kamu mengkhianati amanat-amanat yang sedang dipercayakan kepadamu, sedang kamu mengetahui."

Dalam perspektif hukum perdata akad murabahah merupakan perjanjian jual beli dengan tambahan keuntungan yang disepakati bersama. Jual beli menurut KUHPerdata adalah suatu perjanjian bertimbal balik dalam mana pihak yang satu (si penjual) berjanji untuk menyerahkan hal milik atas suatu barang, sedang pihak yang lainnya (si pembeli) berjanji untuk membayar harga yang terdiri atas sejumlah uang sebagai imbalan dari perolehan hak milik tersebut, yang dimaksud disini adalah jual beli secara tunai. Perkataan jual beli menunjukkan bahwa dari satu pihak perbuatan dinamakan menjual, sedangkan dari pihak yang lain dinamakan membeli. (Subekti, 1995:2) Sifat konsensual dari jual beli tersebut ditegaskan dalam pasal 1458 KUHPerdata yang menyatakan bahwa jualbeli dianggap sudah terjadi antara kedua belah pihak seketika setelah mereka mencapai sepakat tentang barang dan harga, meskipun barang itu belum diserahkan maupun harganya belum dibayar. Hal ini berbeda dengan hukum Islam yaitu bahwa jual beli harus memenuhi syarat rukunnya yang meliputi adanya penjual dan pembeli, adanya barang dan adanya ijab qobul. (Rachmat, 1998:76)

Dalam implementasinya akad murabahah di BMT BUS dilakukan dengan pembayaran angsuran sehingga sering kali anggota (debitor) wan prestasi dengan berbagai alasan antara lain pembayaran angsuran tidak sesuai dengan yang disepakati, terlambat membayar bahkan tidak mau 
membayar angsuran sama sekali atau bahkan macet dalam pembayaran. Berdasarkan Pasal 10 Peraturan Bank Indonesia No. 7/2/PBI/ 2005 tentang penilaian kualitas aktiva bank umum dapat dikategorikan menjadi 5 kategori yaitu : lancar, dalam perhatian khusus, kurang lancar, diragukan dan macet. Macet apabila Terdapat tunggakan angsuran pokok dan/atau bunga lebih dari 270 hari. Akibatnya pihak krediturlah yang banyak dirugikan. Dalam pandangan hukum perdata tidak dipenuhinya prestasi oleh debitor dapat dikatakan sebagai wanprestasi. Wanprestasi artinya tidak memenuhi sesuatu yang diwajibkan seperti yang telah ditetapkan dalam perikatan.

Wanprestasi atau kelalaian dalam memenuhi isi akad di dalam hukum Islam disebut taqsir. Kelalaian menurut madzhab Hanafi merupakan salah satu bentuk dari sifat lupa (nisyan) dan dikatakan jika pelakunya dalam keadaan sadar, maka kelalaian yang demikian tidak dapat dijadikan alasan yang dapat membebaskan seseorang dari pertanggungjawaban atas perbuatannya. (Muhkhlas, 2010:53) Setiap kerugian yang disebabkan kelalaian seseorang, wajib diganti karena harta dan jiwa manusia mendapatkan perlindungan dalam syariah Islam. Wanprestasi dalam Al Qur'an dan hadis tidak dijelaskan secara terperinci, akan tetapi hanya berupa ketentuan-ketentuan secara umum. Sebagaimana dalam (Q.s. al-Maidah (5): 1) :

$$
\text { يأيها الذين ءامنوا أوفو ا بالعقود }
$$

Artinya : "Hai orang-orang yang beriman penuhilah akad-akad itu

Selanjutnya dalam (Q.s. at-Taubah (9): 4) :

$$
\begin{aligned}
& \text { إلا آلذين عاهدتم من آلمشركين ثم لم ينقصوكم شيأ ولم يظاهروا عليكم } \\
& \text { أحدا فأتمو إليهم عهدهم إلى مدتهم ان الله يحب المبن المتقين }
\end{aligned}
$$

Artinya: "Kecuali orang-orang yang musyrikin yang kamu telah mengadakan perjanjian (dengan mereka) dan mereka yang tidak mengurangi sesuatupun (dari isi perjanjian) mu dan tidak pula mereka membantu seseorang memusuhi kamu, maka terhadap mereka itu penuhilah janjimu sampai batas waktunya, sesungguhnya Allah menyukai orang-orang yang bertaqwa".

Pembiayaan murabahah di BMT BUS juga mengalami kemacetan dalam pembayaran yang dilakukan oleh anggota. Secara garis besar terdapat dua hal yang menyebabkan kredit macet dalam pembiayaan murabahah yaitu faktor internal dan faktor eksternal.

1. Faktor internal

a. Ketidaktelitian dari karyawan dalam memberikan pembiayaan, dapat meliputi:

1) pembiayaan murabahah yang diberikan ternyata juga digunakan untuk pembiayaan di tempat lain 
2) objek jaminan tidak sesuai dengan dengan nama anggota yang memperoleh pembiayaan

3) objek jaminan nilainya lebih rendah dari pembiayaan yang diberikan pada anggota

4) nama pemberi jaminan secara formal tidak menandatangani perjanjian pembiayaan.

b. Lemahnya pengawasan pembiayaan oleh pimpinan, meliputi:

1) kontrol terhadap pembiayaan tidak dikoreksi secara komprehensif

2) pimpinan hanya tidak melakukan secara periodik terjun langsung ke lapangan

c. lemahnya akad perjanjian, meliputi:

1) Akad perjanjian yang ditawarkan pada anggota tidak menguntungkan pihak BMT

2) tidak semua perjanjian pembiayaan mengikuti prosedur hukum yang berlaku.

2. Faktor eksternal;

a. BMT tidak langsung berhubungan dengan BI (Bank Indonesia) ceking sehingga anggota yang bermasalah dalam pembiayaan tidak terdeteksi.

b. Pada awalnya anggota sudah bermasalah dengan Bank Indonesia

c. Lemahnya pihak BMT mendetekti pembiayaan bermasalah

d. Anggota pailit

e. Problem keluarga, misalnya perceraian

f. Itikat buruk anggota

Dari uraian diatas tampak bahwa macetnya pembiayaan murabahah disebabkan oleh internal, hal ini senada dengan yang diuraikan oleh Siswanto Sutoyo (Siswanto: 216) yang menyatakan bahwa secara internal, keteledoran perbankan yang tidak mematuhi peraturan pemberian kredit yang telah ditetapkan akan mengakibatkan kredit macet. Hal ini dapat dilihat dari pemberian pembiayaan murabahah dengan objek jaminan. Objek jaminan yang lebih rendah akan membuat debitur malas untuk melakukan pembayaran karena apabila debitur wan prestasi maka objek jaminan nilainya lebih rendah dari pembiayaan yang telah dikeluarkan. Bahkan terkadang pemilik objek jaminan (debitur penjamin) tidak menandatangani perjanjian pembiayaan murabahah, hal ini juga menyulitkan dari pihak kreditur untuk melakukan eksekusi.

Secara eksternal penyebab pembiayaan macet adalah para anggota yang macet tersebut memang sejak awal memang mempunyai potensi bermasalah masalah. Hal ini yang sulit terdeteksi karena BMT tidak tidak masuk dalam akses BI ceking, sehingga tidak bisa melihat apakah calon anggota yang menerima pembiayaan tersebut sudah masuk blacklist oleh 
BI apa tidak. Dapat dipastikan apabila sudah di blacklist oleh BI berarti kreditnya diperbankkan sudah macet atau bermasalah terhadap pembayarannya. Macetnya bisa disebabkan oleh faktor ekonomi, atau pailit sebagaimana diuraikan oleh Supriyadi yang menyatakan bahwa alasan klasik yang sering disampaikan oleh para debitur yang macet adalah usahanya lagi pailit/bangkrut, sulitnya ekonomi. Pailitnya usaha tersebut dapat disebabkan oleh merosotnya ekonomi, salah urus usaha atau kurangnya pengalaman dalam usaha. Namun demikian ada juga pembiayaan yang macet disebabkan oleh itikat buruk dari debitur yang memang sejak semula sengaja tidak ingin melunasi pembiayaan yang telah diterima. Itikad buruk merupakan salah satu faktor yang menyebabkan kredit macet, yang telah direncanakan tidak mengembalikan kreditnya. Selanjutnya adalah problem keluarga juga bisa menjadi faktor eksternal terhadap kredit macet, misalnya karena perceraian. Biasanya pasca perceraian anggota yang macet maka mereka saling melempar tanggungjawab untuk memenuhi kewajiban pembayaran terhadap pembiayaan yang pernah diperoleh. (Supriyadi, 2010:2)

\section{Desain penyelesaian kredit macet pembiayaan Murabahah}

\section{Penyelesaian secara internal}

Penyelesaian internal ini dilakukan oleh tim khusus yang yang dibentuk di masing masing cabang di seluruh BMT BUS seluruh Indonesia dengan didampingi oleh remedial dari kantor BMT BUS pusat. Penyelesaian ini merupakan bagian dari penyelesaian secara non litigasi atau penyelesaian di luar pengadilan. Penyelesaian ini sering disebut dengan Alternative Dispute Resolution (ADR) yaitu menunjukkan pranata penyelesaian sengketa di luar pengadilan melalui prosedur yang disepakati para pihak (self-governing system). Penyelesaian sengketa melalui Alternative Dispute Resolution (ADR) memiliki kebaikan atau keunggulan daripada proses penyelesaian melalui ajudiksi. Penyelesaian sengketa dibandingkan melalui Alternative Dispute Resolution (ADR) jauh lebih efisien dan efektif dengan penyelesaian sengketa melalui institusi ajudiksi, di mana penyelesaian lebih cepat, biaya murah, dan paling penting menghasilkan kesepakatan yang dapat diterima para pihak. Para pihak dapat mengatur sendiri cara dalamanya waktu penyelesaian sengketa dimaksud.

William Ury, J.M. Brett dan S.B. Golderg menyatakan bahwa penyelesaian secara non litigasi bertujuan pertama, mengurangi kemacetan di pengadilan. Banyaknya kasus yang diajukan ke pengadilan menyebabkan proses pengadilan sering kali berkepanjangan, sehingga memakan biaya yang tinggi dan sering memberikan hasil yang kurang memuaskan; kedua, meningkatkan 
ketertiban masyarakat dalam proses penyelesaian sengketa; ketiga, memperlancar serta memperluas akses ke pengadilan; keempat, memberikan kesempatan bagi tercapainya penyelesaian sengketa yang menghasilkan keputusan yang dapat diterima oleh semua pihak dan memuaskan. (William, 2003:10)

Berdasarkan data yang diperoleh dapat diketahui bahwa penyelesaian kredit macet dalam pembiayaan murabahah tetap diupayakan pencegahan dini agar pembayaran angsuran lancar. Oleh karena itu ketika pembiayaan tersebut terdapat potensi non lancar maka pihak BMT BUS akan berupaya menyelesaikan agar tidak terjadi macet. Langkah langkah yang dilakukan oleh pihak BMT BUS dalam penyelesaian secara non litigasi ini meliputi tahapan tahapan sebagai berikut:

\section{a. Membuka Dokumen}

Pembukaan dokumen ini dapat diketahui akad pembiayaan yang dilakukan oleh para pihak baik oleh pihak BMT BUS maupun pihak yang menerima pembiayaan. Dengan demikian akan terlihat siapa saja yang terlibat dalam pembiayaan, siapa yang menjadi referensi (debitur penjamin) sehingga akan lebih jelas dan lebih mudah dalam penyelesaiannya.

\section{b. Diskripsi anggota (debitur)}

Hal ini memberikan gambaran tentang karakteristik anggota yang diilustrasikan ke dalam narasi yang meliputi aspek ekonomi, psikologi maupun kulturala dari anggota. Bertolak dari ilustrasi tersebut kemudian anggota ditunjukkkan tentang dokumen pembiayaan yang pernah ditandatangai, hal ini bertujuan untuk mengingatkan kembali memori anggota pada saat menerima pembiayaan. Pembiayaan dapat meliputi pembiayaan produktif dan pembiayaan konsumtif. Dalam pembiayaan ini tentu juga akan terlihat jaminan yang menjadi anggunan yang diserahkan oleh anggota kepada pihak BMT.

\section{c. Persuasif}

Pendekatan ini yang diutamakan dalam rangka untuk menyelesaikan kredit macet dalam pembiayaan murabahah. Oleh karena itu anggota akan ditanya komitmennya dalam penyelesaian masalah pembiayaan yang pernah diterima. Apabila anggota telah mempunyai komitmen untuk menyelesaikan maka anggota harus membuat perjanjian atau pernyataan tentang jangka waktu dan cara penyelesainnya ataupun pembayarannya. Penyelesaian dapat dilakukan dengan cara reschedule (retrukturisasi) pembayaran atau bahkan mengangsur kembali sesuai dengan kesepakatan daalam akad perjanjian pada saat menerima 
pembiayaan. Pihak BMT harus mampu menggali kemampuan dari anggota dengan memberikan alternatif alternatif solusi penyelesaian.

Tahapan proses penyelesaian di atas dapat dibenarkan secara hukum karena telah sesuai dengan Undang undang nomor Undangundang Nomor 30 tahun 1999 telah menyediakan beberapa pranata pilihan penyelesaian sengketa secara damai yang dapat ditempuh para pihak untuk menyelesaikan sengketa atau beda pendapat perdata mereka. Pembukaan dokumen merupakan hal pernting karena dalam dokumen tersebut dapat diketahui akad pembiayaan yang dituangkan dalam suatu perjanjian. Menurut Pasal 1338 KUH Perdata bahwa perjanjian merupakan undang undang para pihak, sehingga ketika terjadi perselisihan dalam pembiayaan maka akta perjanjianlah yang menjadi dasar penyelesainnya.

\section{Penyelesaian secara eksternal}

Penyelesaian ini melibatkan pihak ketiga sebagai upaya kredit macet dalam pembiayaan murabahah tidak berlarut larut dan cepat selesai sehingga pihak BMT (kreditur) tidak banyak dirugikan. Pihak ketiga ini dilaksanakan oleh organisasai pengacara yang berkedudukan di Kudus yaitu dari Asosiasi Pengacara Syari'ah Indonesia (APSI). Penggunaan pengacara APSI oleh BMT karena adanya kesamaan visi misi sehingga dalam penyelesaiannya juga berbasis syari' ah. Disamping itu juga APSI mempunyai pengalaman menjadi konsultan hukum di beberapa perusahaan hal ini menambah keyakinan dari BMT untuk mengunakan jasa konsultan hukum tersebut.

Penyelesaian kredit macet dalam pembiayaan murabahah dilakukan dengan cara pemetaan wilayah berdasarkan kantor cabang yang dimiliki oleh BMT. Hal ini dimaksudkan untuk memudahkan penyelesaian agar tidak terjadi tumpang tindih penyelesaiannya. Masing masing cabang menyerahkan berkas lengkap kepada kantor konsultan hukumnya yang meliputi; akad perjanjian, jumlah pembiayaan yang dikeluarkan berikut margin yang disepakati, objek jaminan yang dijadikan anggunan dan ilustrasi anggota yang macet dalam pembiayaan murabahah. Selanjutnya pihak konsultan hukum akan mempelajari berkas tersebut baik sebara yuridis maupun secara sosiologis. Yuridis akan memetakan posisi hukum dari kreditur dan debitur agar penyelesaiannya tidak bertentangan dengan hukum yang berlaku. Secara sosiologis karena karakteristik sosial masyarakat berbeda sehingga penyelesaianya juga akan menggunakan pendekatan yang berbeda.

Secara sosiologis juga melihat aspek anggota (debitur) sebagai bagian dari bermasyarakat dengan kultur hukumnya, karena hukum 
memiliki hubungan timbal balik dengan masyarakat. Sebagaimana diungkapkan oleh bahwa hukum memiliki hubungan timbal balik dengan masyarakatnya, karena hukum itu merupakan sarana pengatur dan bekerja di dalam masyarakat. Itulah sebabnya, hukum tidak terlepas dari gagasan-gagasan maupun pendapat-pendapat yang hidup di kalangan anggota masyarakat. (Esmi, 2005:85) Selanjutnya dikatakan bahwa hukum yang dianut sarat dengan nilai-nilai yang dianut masyarakat. Nilai-nilai inilah yang menentukan kultur atau budaya hukum masyarakat. Hal senada juga dikatakan Lawrence M. Friedman bahwa kultur hukum merupakan sikap-sikap dan nilai-nilai yang dimiliki masyarakat yang berhubungan dengan hukum dan lembagalembaganya baik yang bersifat positif maupun negatif. Unsur inilah yang menentukan mengapa seseorang itu patuh atau tidak patuh terhadap peraturan. Sesungguhnya kultur hukum berfungsi sebagai "motor penggerak keadilan" yakni menjembatani sistem hukum dengan sikap manusia dalam suatu masyarakat. (Esmi, 2005:89)

Penyelesaian oleh pihak ketiga (Pengacara) inipun lebih mengutamakan penyelesaian di luar pengadilan karena dianggap lebih efektif dalam mencapai tujuanya. Penyelesaian hukum, menurut Satjipto Rahardjo adalah cara penyelesaian masalah ataupun perkara dengan melakukan suatu solusi hukum. (Sajipto. 2006:190) Penyelesaian hukum tersebut, didasarkan pada pandangan hidup yang dianut oleh masyarakat itu sendiri. Pandangan hidup ini dapat diidentifikasikan sebagai suatu pandangan objektif dari orang-orang yang ada dalam masyarakat mengenai apa dan bagaimana hidup ini. Pandangan hidup ini menjadi dasar perumusan nilai, norma atau kaidah yang mengatur perilaku individu dalam masyarakat. Selanjutnya beliau menyatakan sebagai suatu strategi sosiologis, yaitu dengan melihat kenyataan dalam masyarakat untuk menyelesaikan hukum yang dapat memuaskan rasa keadilan masyarakat. (Sajipto. 2006:192) Strategi atau pola sosiologis, tersebut menekankan pada soal efisiensi untuk mencari pemecahan alternatif terhadap hukum. (Sajipto. 2006:194)

Langkah langkah hukum yang ditempuh oleh pengacara/ advokat setelah menerima seluruh berkas dari BMT meliputi:

\section{a. Somasi hukum}

Langkah hukum yang ditempuh oleh kuasa hukum yang pertama adalah memberikan somasi terhadap anggota. Peringatan atau somasi tersebut dilakukan sebanyak tiga kali, peringatan pertama berisi supaya pihak yang debitur segera menyelesaikan permasalahannya. Cara penyelesaiannya dapat dilakukan dengan dua cara yaitu: 1) Debitur menyerahkan objek jaminan kepada kreditur. 2) Kreditur tidak menarik benda yang menjadi objek 
jaminan dengan catatan debitur membayar atau melunasi sesuai dengan ketentuan/ kesepakatan saat dibuatnya.

Langkah kedua, apabila somasi pertama tidak diindahkan maka kuasa hukum penerima fidusia memberikan somasi yang kedua yang pada intinya anggota diundang untuk hadir di kantor kuasa hukum dengan membawa kendaraan jika yang menjadi objek adalah kendaraan. Jika yang menjadi objek jaminan adalah bendak tidak bergerak maka akan diperingatkan untuk segera menyelesaikan. Pada saat inilah terjadi negosiasi untuk menyelesaikan negosiasi ini merupakan pertemuan antara para pihak yaitu pihak kreditur dan debitut. Selanjutnya somasi ketiga, hal ini dilakukan apabila debitur tidak menanggapai atau merespon terhadap somasi sebelumnya. Somasi ketiga pada intinya jika debitur tetap tidak menyelesaiakan pembiayaan yang pernah diterima maka objek jaminan akan dieksekusi sesuai dengan hukum yang berlaku.

b. Negosiasi

Hal ini yang ditempuh kuasa hukum dalam rangka mempercepat penyelesaian kredit macet dalam pembiayaan murabahah. Gary Goodpaster, (Gary, 1993:5) menjelaskan negosiasi merupakan proses upaya untuk mencapai kesepakatan dengan pihak lain, suatu proses interaksi dan komunikasi yang dinamis dan beraneka ragam, dapat lembut dan bernuansa, sebagaimana manusia itu sendiri. Orang bernegosiasi dalam jumlah yang tidak terhitung jumlahnya dimana mereka membutuhkan atau menginginkan sesuatu yang dapat diberikan ataupun ditahan oleh pihak atau orang lain, bila mereka menginginkan untuk memperoleh kerja sama, bantuan atau persetujuan orang lain atau ingin menjelaskan atau mengurangi persengketaan atau perselisihan.

Negosiasi biasanya dilakukan dalam perkara yang tidak terlalu rumit. Suatu hal yang penting dalam bernegosiasi adalah suatu itikat baik dari para pihak untuk secara bersama-sama duduk dan menyelesaikan masalah. Apabila kepercayaan maupun keinginan untuk mendapatkan suatu kesepakatan di antara para pihak telah luntur, maka negosiasi akan menjadi suatu upaya yang sia-sia. Namun demikian, jika para pihak dapat duduk secara bersama-sama dengan itikat baik dan niat untuk mencari suatu kesepakatan.

\section{c. Mediasi}

Apabila proses negosiasi gagal maka akan ditempuh jalur mediasi yaitu melibatkan pihak ketiga yang netral. Collins English Dictionary and Thesaurus didalamnya menyebutkan bahwa mediasi adalah kegiatan menjembatani antara dua pihak yang bersengketa guna menghasilkan kesepakatan (agreement). (Lorna, 2007:510) 
Kegiatan ini dilakukan oleh mediator sebagai pihak yang ikut membantu mencari berbagai alternatif penyelesaian sengketa. Posisi mediator dalam hal ini adalah mendorong para pihak untuk mencapai kesepakatan-kesepakatan yang dapat mengakhiri perselisihan dan persengketaan. Ia tidak dapat memaksa para pihak untuk menerima tawaran penyelesaian sengketa darinya. Para pihaklah yang menentukan kesepakatan-kesepakatan apa yang mereka inginkan. Mediator hanya membantu mencari alternatif dan mendorong mereka secara bersama-sama ikut menyelesaikan sengketa.

Mediasi adalah cara penyelesaian sengketa di luar pengadilan melalui perundingan yang melibatkan pihak ketiga yang bersikap netral (non-intervensi) dan tidak berpihak (impartial) kepada pihakpihak yang bersengketa serta diterima kehadirannya oleh pihak-pihak yang bersengketa. Pihak ketiga tersebut disebut "mediator" atau "penengah", yang tugasnya hanya membantu pihak-pihak yang bersengketa dalam menyelesaikan masalahnya dan tidak mempunyai kewenangan untuk mengambil keputusan (Rochmadi, 2009:79). Dengan perkataan lain, mediator di sini hanya bertindak sebagai fasilitator saja. Dengan mediasi diharapkan dicapai titik temu penyelesaian masalah atau sengketa yang dihadapi para pihak, yang selanjutnya akan dituangkan sebagai kesepakatan bersama. Pengambilan keputusan tidak berada di tangan mediator, tetapi di tangan para pihak yang bersengketa. Harapannya adalah dapat membantu proses kredit macet dalam pembiayaan murabahah agar tidak berlarut larut.

\section{d. Eksekusi}

Eksekusi merupakan alternatif terakhir yang dilakukan oleh pihak kreditur apabila debitur telah melakukan wan prestasi. Hal ini dilakukan dengan pertimbangan pertimbangan tertentu dimana upaya penyelesaian kredit macet dalam pembiayaan murabahah telah dilakukan baik melalui internal maupun eksternal (pihak ketiga). Sebelum melaksanakan eksekusi oleh kreditur akan dipertimbangkan apakah pembiayaan murabahah tersebut dengan jaminan atau tanpa jaminan. Jika tanpa jaminan maka kreditur akan berupaya untuk melakukan akad ulang supaya pihak debitur memberikan jaminan dalam akad ulang. Tujuannya adalah untuk memudahkan kreditur dalam mengeksekusi objek yang menjadi jaminan pembiayaan. Jika pembiayaan murabahah dengan menggunakan jaminan maka akan dilihat apakah jaminannya benda bergerak ataupun tidak bergerak. Selanjutnya diidentifikasi objek jaminan tersebut apakah masuk kategori jaminan fidusia atau hak tanggungan. Identifikasi objek jaminan ini bertujuan untuk memudahkan bagi kreditur dalam 
melakukan eksekusi. Keberadaan objek jaminan ini sebenarnya untuk menjaga kekhawatiran dari kreditur agar debitur mau melunasi pembiayaan murabahah yang telah dikeluarkan oleh kreditur (BMT BUS), sehingga pihak kreditur tidak mengalami kerugian akibat debitur wan prestasi.

Apabila anggota tidak ada kemampuan lagi untuk membayar baik secara angsuran atupun telah di-rechedule maka alternatif yang ditawarkan adalah eksekusi di bawah tangan. Pada tahapan ini dibuat kesadaran bersama bahwa pembiayaan yang telah dikeluarkan oleh BMT adalah milik semua anggota koperasi (BMT BUS) sehingga harus dipertanggungjawabkan kepada seluruh anggota koperasi. Apabila terdapat jaminan pada saat pembiayaan maka anggota supaya ridlo/ikhlas apabila jaminannya dijual dibawah tangan dengan tujuan untuk melunasi pembiayaan yang pernah dikeluarkan. Dengan ketentuan bahwa apabila hasil penjualan jaminan terdapat kelebihan, setelah dikurangi pokok dan margin yang disepakati, maka kelebihan penjualan akan diserahkan kepada anggota. Tetapi yang lebih rumit apabila pada waktu pembiayaaan tanpa disertai jaminan maka pihak BMT harus menciptakan kesadaran kepada anggota bahwa apabila anggota mempunyai asset maka asset tersebut dapat digunakan untuk melunasi pembiayaannya.

\section{KESIMPULAN}

Faktor faktor yang mempengaruhi kredit macet dalam pembiayaan murabahah adalah dua faktor yaitu faktor internal yang disebabkan oleh ketidaktaatan pihak kreditur dalam mematuhi peraturan pemberian pembiayaan yang telah ditetapkan, dan Faktor eksternal yaitu faktor dari luar BMT yang disebabkan karena BMT tidak langsung berhubungan dengan BI (Bank Indonesia) ceking sehingga anggota yang sejak awal bermasalah dalam pembiayaan tidak terdeteksi disamping itu juga karena anggota pailit.

Desain penyelesaian kredit macet dalam pembiayaan murabahah juga dilakukan melalui dua cara yaitu secara internal dengan cara penyelesaian yang dilakukan oleh tim khusus yang dibentuk di masing masing cabang di seluruh Indonesia dengan didampingi oleh remedial dari kantor pusat. Dan eksternal Penyelesaian ini melibatkan pihak ketiga yang dilaksanakan oleh organisasai pengacara yang dari Asosiasi Pengacara Syari'ah Indonesia (APSI). Penggunaan pengacara APSI oleh BMT karena adanya kesamaan visi misi sehingga dalam penyelesaiannya juga berbasis syari'ah.

Perlu adanya pengawasan dan penertiban secara ketat oleh pemerintah terhadap lembaga keuangan syariah agar mentati peraturan 
perundangan yang berlaku sehingga pembiayaan syariah menjadi solusi dalam pembangunan ekonomi nasional.

Perlu aturan yang jelas yang dikeluarkan oleh pihak pemerintah terhadap pihak ketiga yang terlibat dalam penyelesaian pembiayaan yang berbasis syariah agar memberi perlindungan bagi lembaga keuangan syariah dan pihak ketiga yang terlibat dalam penyelesaian kredit macet.

\section{DAFTAR PUSTAKA}

Faisal, Restrukturisasi Pembiayaan Murabahah Dalam Mendukung Manajemen Resiko Sebagai Implementasi Prudential Principle Pada Bank Syariah Di Indonesia, Jurnal Dinamika Hukum, Vol 11 No. 3 September 2011

Faisal, Sanafiah,(1990), Penelitian Kualitatif: Dasar-Dasar dan Aplikasinya, Observasi Terseleksi, Malang:Yayasan Asah Asih Asuh.

Gary Goodpaster,(1993), Negosiasi dan Mediasi, Sebuah Pedoman Negosiasi dan Penyelesaian Sengketa Melalui Negosiasi,Jakarta: ELIPS Project.

Hamoudi, Haider Ala, Muhammad's Social Justice or Muslim Cant? : Langdelleanism And The Failure Of Islamic Finance, Cornell International Law Journal, 40 Cornell International 89, Winter 2007

Lorna Gilmour, Penny Hand, dan Cormac Mc Keown (eds.), (2007), Collins English Dictionary and Thesaurus, Third Rdition, (Great Britain: Harper Collins Publishers.

Martin H. Manser,(1995), Oxford Learner;s Pocket Dictionary, New Edition, Oxford: Oxford University Press.

Maulidiana, Lina, Penerapan Prinsip-Prinsip Murabahah Dalam Perjanjian Islam (Kajian Operasional Bank Syariah Dalam Modernisasi Hukum), Jurnal Sains Dan Informasi, Fakultas Hukum Universitas Sang Bumi Ruwa Jurai, No. 7, tahun 2011

Mukhlas, Tesis,(2010), Implementasi gadai Syari'ah dengan akad Murabahah dan Rahn (Studi di Pegadaian Syari'ah cabang Mlati Sleman Yogyakarta, Program Magister Ilmu Hukumm Fakultas Hukum Universitas Sebelas Maret Surakarta.

Nasution,(1992), Metode Penelitian Naturalistik Kualitatif, Tarsito Bandung. Rahardjo, Satjipto,(2004), Ilmu Hukum, Pencarian, Pembebasan dan Pencerahan, Surakarta:Muhammadiyah University press.

Rahayu, Esmi Warassih,(2005), Pranata Hukum Sebuah Telaah Sosiologis, PT. Suryandaru Utama.

Rahma, Yusuf Aziz,(2010), Prosedur pembiayaan dan penanganan masalah pada BMT Arafah, Penelitian, UNS Surakarta.

Rivai, Harif Amali, dkk, Identifikasi Faktor Penentu Keputusan Konsumen Dalam Memilih Jasa Perbankan : Bank Syariah Vs Bank Konvensional, Jurnal Center For Banking Research Universitas Andalas, 2006 
Desain Penyelesaian Kredit Macet dalam Pembiayaan Murobahah di BMT Bina Ummat Sejahtera

Satjipto Rahardjo,(2006), Sisi-Sisi Lain Dari Hukum di Indonesia, Jakarta: Penerbit Buku Kompas.

Siamat, Dahlan,(1993), Manajemen Bank Umum, Jakarta: Intermedia.

Soemitro Ronny Hanutijo,(1985), Motodologi Penelitian Hukum, Ghalia Indonesia.

Subekti,(1995), Aneka Perjanjian, Bandung: Citra Aditya Bakti.

Sudarto,(1986), Hukum dan Hukum Pidana, Bandung: Penerbit Alumni.

Supriyadi, Desain Penyelesaian Kredit Macet Di BPR BKK Jepara Melaui Jalur Non Litigasi, Iqtishadia, Jurnal Ekonomi dan Bisnis Islam, Program Studi Ekonomi Islam jurusan Syariah, STAIN Kudus, Edisi IX Desember 2010, ISSN: 1979-0724

Syafei, Rachmat,(1998), Fiqh Muamalah, Bandung: CV. Pustaka Setia.

Usman, Rohmadi,(2009), Pilihan Penyelesaian Sengketa di Luar Pengadilan, Bandung: Citra Aditya Bhakti.

William Ury, J.M. Brett dan S.B. Golderg,(2003), Getting Disputes Resolved hlm. 35 sebagaimana dikutip Rohmadi Usman, Pilihan Penyelesaian Sengketa di luar pengadilan, Bandung: Citra Aditya Bhakti,.

Yin, Robert K, (2006), Studi Kasus, Desain dan Metode, Jakarta: PT. Radja Grafindo.

Zamroni,(1992), Pengembangan Pengantar Teori Sosial, Yogyakarta: Tiara Yoga.

Internet

Republika online, http://www.republika.co.id/berita/ekonomi/syariah ekonomi/15/03/22/nlmhlb-aset-bmt-indonesia-capai-rp-47-triliun, diakses tanggal 1 Maret 2016

Bank Indonesia, Sekilas perbankan syari'ah di Indonesia, http://www.bi.go.id/id/perbankan/syariah/Contents/Default.as px, diakses tanggal 3 Maret 2016

Unisba, $\quad$ http:/ / pasca.unisba.ac.id/akad-murabahah-danimplementasinya-pada-syariah-dihubungkan-dengan-kebolehanpraktek-murabahah-menurut-para-ulama/ diakses 4 Maret 2016 